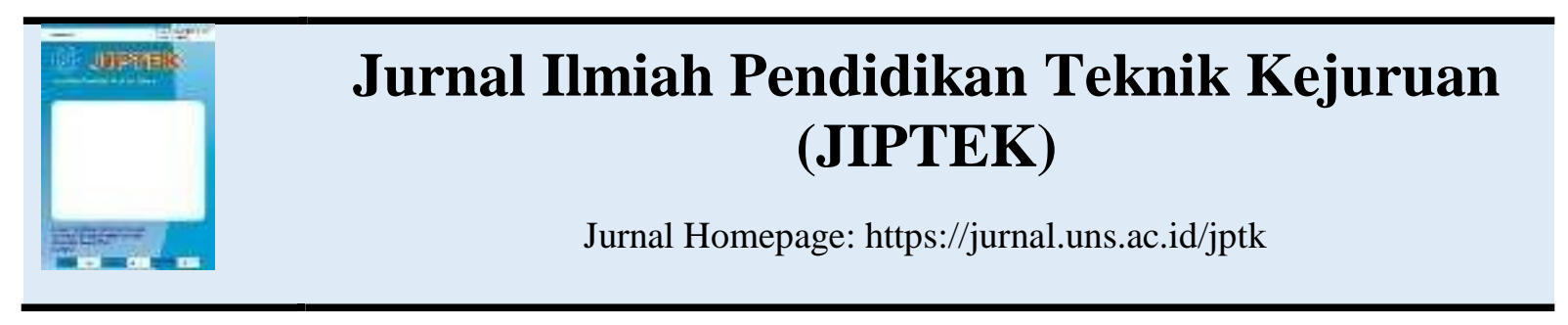

\title{
EFEKTIVITAS PENGGUNAAN MEDIA PEMBELAJARAN VIDEOSCRIBE UNTUK MENINGKATKAN MOTIVASI BELAJAR DAN HASIL BELAJAR SISWA PADA MATA PELAJARAN DASAR DESAIN GRAFIS DI SMK NEGERI 5 SURAKARTA
}

\author{
Luluk Monitasari ${ }^{1}$, Endar Suprih W. ${ }^{2}$, Yusfia Hafid Aristyagama ${ }^{3}$ \\ 1,2,3 Program Studi Pendidikan Teknik Informatika dan Komputer, FKIP, Universitas Sebelas Maret \\ Surakarta \\ Jalan Ahmad Yani 200 Surakarta \\ Email: luluk13bea@gmail.com
}

\begin{abstract}
ABSTRAK
Berdasarkan hasil observasi di SMK N 5 Surakarta pada mata pelajaran Dasar Desain Grafis menunjukkan bahwa motivasi dan hasil belajar siswa masih rendah. Berdasarkan hasil belajar sebelumnya didapatkan sebesar $18,1 \%$ peserta didik yang mendapatkan nilai di atas kriteria ketuntasan minimum $(\mathrm{KKM} \geq 75)$ sedangkan tingkat motivasi belajar peserta didik menunjukkan motivasi belajar yang masih rendah dan kurang bersemangat dalam belajar. Berdasarkan permasalahan tersebut diperlukannya usaha untuk meningkatkan motivasi dan hasil belajar dengan menggunakan media pembelajaran Videoscribe dalam pembelajaran. Pemilihan media videoscribe karena mampu menyajikan visual yang berasal dari gabungan teks, suara, gambar yang digabungkan menjadi animasi sesuai dengan kebutuhan dalam belajar dasar desain grafis yang berkaitan dengan visual. Penelitian ini menggunakan metode quasi exsperimental design dengan desain nonequivalent control group design. Untuk mengukur motivasi digunakan kuisoner, sedangkan hasil belajar siswa diukur dengan menggunakan tes. Hasil uji hipotesis penelitian menunjukkan adanya peningkatan motivasi belajar pada kelas eksperimen dengan Ngain sebesar 0,46 dengan kategori sedang. Sedangkan hasil belajar pada kelas eksperimen juga mengalami peningkatan lebih tinggi dari pada kelas kontrol dengan Ngain sebesar 0,34 dengan kategori sedang.
\end{abstract}

Kata kunci: Efektivitas, Media Pembelajaran, Videoscribe, Motivasi Belajar, Hasil Belajar

\begin{abstract}
Based on the results of observations at SMKN 5 Surakarta in the Basic Graphic Design subject, it shows that student motivation and learning outcomes are still low. Based on the previous learning results, it was found that $18.1 \%$ of students scored above the minimum completeness criteria $(K K M \geq 75)$ while the level of learning motivation of students showed that learning motivation was still low and less enthusiastic in learning. Based on these problems, an effort is needed to increase motivation and learning outcomes using Videoscribe learning media in learning. The selection of videoscribe media is because it is able to present visuals that come from a combination of text, sound, images that are combined into animation according to the needs in learning basic graphic design related to visuals. This study used a quasi experimental design with a nonequivalent control group design. Questionnaires were used to measure motivation, while student learning outcomes were measured using tests. The results of the research hypothesis test showed an increase in learning motivation in the experimental class with Ngain of 0.46 in the moderate category. While the learning outcomes in the experimental class also increased higher than the control class with Ngain of 0.34 in the moderate category.
\end{abstract}

Keywords: Effectiveness, Learning Media, Videoscribe, Motivation Learners, Learning Outcomes 


\section{PENDAHULUAN}

Permasalahan yang sering terjadi di lembaga pendidikan khususnya SMK adalah sulitnya siswa dalam memahami materi yang diajarkan, terutama untuk Kurikulum K13 (Giana \& Lutfi, 2019). SMK N 5 Surakarta sudah memiliki fasilitas yang memadai, seperti penggunaan proyektor untuk pembelajaran. Pada mata pelajaran dasar desain grafis guru terbatas menggunakan media seperti powerpoint sebagai penunjang pembelajaran. Media pembelajaran powerpoint yang dianggap tidak tepat mengakibatkan siswa sulit memahami materi pembelajaran serta kurang menarik perhatian siswa. Hal tersebut terbukti sebesar 18,1\% hasil belajar peserta didik yang lulus kriteria ketuntasan minimal (KKM) sebesar 75. Hasil belajar tersebut di dapat dari hasil test materi manipulasi gambar vektor. Sedangkan dilihat dari jawaban data kuisioner siswa, tingkat motivasi masih menunjukkan motivasi belajar yang masih rendah dan kurang bersemangat untuk belajar mata pelajaran dasar desain grafis. Oleh karena itu perlu adanya media guna membantu peserta didik dalam pembelajaran. Ketepatan penggunaan media pembelajaran dapat membantu pendidik memberikan materi yang mudah dipahami serta menjaga motivasi belajar siswa.

Berbagai variasi media belajar yang dapat dimanfaatkan untuk lebih meningkatkan kualitas pembelajaran. Saputra (2017: 3) mengemukakan bahwa penggunaan media audio visual dapat membantu siswa memahami materi selama proses pembelajaran. Salah satunya media pembelajaran audio visual adalah Videoscribe. Videoscribe adalah animasi papan tulis menunjukkan gambargambar yang ditunjukkan dengan latar belakang putih selaras dengan materi pembelajaran yang ditambahkan. Penerapan Videoscribe akan memfasilitasi siswa dalam berpartisipasi dalam pembelajaran (Zulmiyetri et al., 2019). (Audie, 2019). Menurut Khoirudin (2017) videoscribe dapat memperjelas sesuatu hal yang bersifat abstrak, sehingga dapat membantu dalam pembelajaran Dasar Desain Grafis (Setiawan et al., 2019).

Berdasarkan hasil penelitian Dellyardianzah (2017) penggunaan media videoscribe pada mata pelajaran ekonomi dapat meningkatkan hasil post-test secara signifikan. Azis, Taiyeb, \& Muis (2010) dalam penelitiannya menunjukkan adanya pengaruh signifikan penggunaan media berupa video dalam motivasi serta hasil belajar siswa pada materi sistem peredaran darah. Sementara hasil penelitian yang dilakukan oleh Ismail, E. Enawaty (2016) menunjukkan bahwa penggunaan media pembelajaran videoscribe dapat meningkatkan hasil belajar siswa dalam pembelajaran ikatan kimia.

Setelah pemaparan yang telah dilakukan, maka penelitian ini akan menerapkan media videoscribe untuk upaya meningkatkan motivasi serta hasil belajar siswa khususnya dalam mata pelajaran dasar desain grafis. Penggunaan media pembelajaran dengan 
videoscribe dikarenakan sebelumnya peneliti belum pernah menemukan penelitian yang menggunakan media ini dalam pembelajaran dasar desain grafis dan khususnya yang berhubungan dengan variabel peningkatan motivasi dan hasil belajar peserta didik. Sehingga diharapkan penelitian ini dapat menambah referensi pada variable motivasi dan hasil belajar yang digunakan dan dapat menjadi acuan pada penelitian lainnya.

\section{METODE PENELITIAN}

Metode penelitin yang digunakan adalah quasi experimental design dengan desain penelitian nonequivalent control group design. Sebelum diterapkannya penggunaan media Videoscribe kedua kelas dilakukan pretest untuk mengetahui awal kemampuan. Pada akhir penelitian siswa akan diberikan postest serta kuisioner.

Penelitian dilaksanakan di SMK Negeri 5 Surakarta dan dimulai pada bulan 24 Februari hingga 5 Maret 2020. Populasi pada penelitian ini diambil dari siswa kelas X RPL di SMK Negeri 5 Surakarta. Sample yang digunakan dalam penelitian ini adalah kelas XA sebanyak 33 peserta didik sebagai kelas kontrol dan kelas XB sebanyak 33 peserta didik sebagai kelas eksperimen sehingga jumlah total keselururan ada 66 peserta didik. Teknik pengambilan sampel menggunakan cluster random sampling.

Teknik pengumpulan data yang digunakan dalam penelitian ini adalah teknik tes dan teknik kuisioner. Teknik tes yang diberikan berupa pilihan ganda yang di sesuaikan dengan materi dasar desain grafis. Teknik kuisioner untuk mengetahui tingkat motivasi pada peserta didik. Indikator motivasi belajar yang dikembangkan dari Sudjana (2014). Garis besar indikator yang digunakan yaitu:

1. Minat dan perhatian siswa terhadap pembelajaran.

2. Semangat siswa untuk melaksanakan belajarnya.

3. Tanggung jawab dalam mengerjakan tugas-tugas belajarnya.

4. Rasa senang dalam mengerjakan tugas dari guru.

5. Reaksi yang ditunjukkan siswa terhadap stimulus yang diberikan guru.

Teknik analisis data penelitian untuk instrumen menggunakan uji validitas serta uji reliabilitas. Selain itu instrumen juga diuji pembeda, kesukaran serta pengecoh. Data yang telah didapat akan diuji dengan menggunakan uji homogenitas, uji normalitas, uji keseimbangan serta uji hipotesis.

Media pembelajaran menurut Munadi (2010: 5) dapat didefinisikan sebagai penyalur informasi dari sumber terpercaya secara terstruktur oleh pendidik dalam belajar. Media pembelajaran adalah bentuk dari suatu sarana komunikasi dalam bentuk teknologi atau cetak (Rahman \& Amri, 2014: 176). Audio visual (Videoscribe) mempermudah dalam proses belajar mengajar dari segi komunikasi menyampaika, menerima informasi, dapat meminimalisir kesalahan pengertian dan 
memberikan dorongan motivasi untuk mengetahui pengetahuan baru yang lebih banyak (Sadiman, Rahardjo, \& Haryono, 2018: 107).

Belajar adalah hal yang lebih luas dari mengingat saja namun juga mengarah ke pengalaman yang dialami. Hasil belajar tidak hanya sebagai hasil dari latihan yang dilakukan namun memperbaiki kelakuan dari pengalaman (Hamalik, 2001: 27). Hasil belajar menurut Smaldino (2011: 12) terbagi menjadi 3 golongan yaitu:

1. Ranah kognitif adalah belajar yang menggunakan serangkaian verbal/visual atau intelektual.

2. Ranah afektif adalah ranah yang melibatkan perasaan, moral dan sikap. Tujuan dari ranah ini adalah merangsang minat, mendorong perilaku sosial, dan sadar akan etika.

3. Ranah psikomotorik adalah melibatkan keterampilan fisik, manual secara teknis yang sederhana sampai rumit.

Motivasi belajar menurut Pranomo (2014) adalah semua hal yang dapat menggerakkan siswa baik dari dalam atau luar (menyediakan keadaan dengan usaha tertentu) sehingga tujuan yang ingin dicapai dapat terwujud. Hamalik (2001: 158) berpendapat bahwa motivasi merupakan semua perbedaan energi yang ada pada diri sendiri yang ditandai dengan adanya rasa dan reaksi untuk memenuhi tujuan yang ingin dicapai.

\section{PEMBAHASAN}

Berdasarkan hasil uji instrumen kuisioner diperoleh 20 pernyataan valid dari 25 pertanyaan dengan nilai reliabilitas sebesar 0,636. Pada instrumen tes untuk pretest didapatkan hasil 17 soal valid dari 21 soal dengan nilai reliabilitas sebesar 0,653 sedangkan posttest didapatkan 16 soal valid dari 19 soal yang diujikan dengan reliabilitas sebesar 0,684 .

Data hasil belajar yang diperoleh dari hasil pretest serta posttest serta hasil motivasi dari kuisioner diperoleh adanya peningkatan. Berikut disajikan hasil data dari kedua kelas pada Tabel 1 dan Tabel 2.

Tabel 1. Hasil Belajar

\begin{tabular}{lllll}
\hline Kelas & Pre & Post & $\begin{array}{c}N- \\
\text { Gain }\end{array}$ & Ket \\
& \multicolumn{5}{c}{ Kontrol } & 61, & 68,1 & 0,17 & Rendah \\
& 2 & & & \\
\hline Eksperimen & 65, & 76,6 & 0,34 & Sedang \\
& 1 & & & \\
& & & & \\
\hline
\end{tabular}

Tabel 2. Motivasi Belajar

\begin{tabular}{lllll}
\hline Kelas & Aw & Akhir & $\begin{array}{c}N \text { - } \\
\text { Gain }\end{array}$ & Ket \\
& al & & 0,29 & Rendah \\
\hline Kontrol & 66 & 75,97 & 0,46 & Sedang \\
\hline Eksperimen & 69, & 83,82 & 0,40 & \\
& 64 & & & \\
\hline
\end{tabular}

Hasil perhitungan statistik untuk rata-rata dari data penelitian ditunjukkan dalam grafik berikut:

\section{HASIL PENELITIAN DAN}




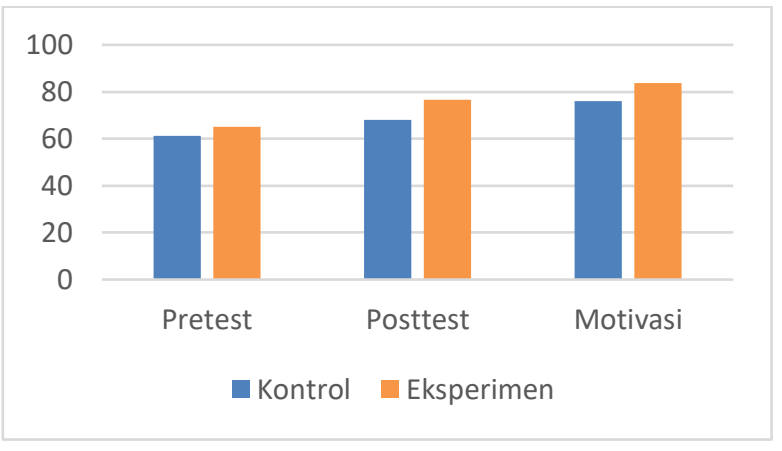

Gambar 1. Grafik Nilai Rata-Rata

Hasil uji hipotesis dalam penelitian ini diantaranya yaitu:

\section{Hipotesis Pertama}

Ha : Terdapat peningkatan motivasi belajar siswa pada penggunaan media pembelajaran videoscribe.

2. Hipotesis Kedua

Ha : Terdapat peningkatan hasil belajar siswa pada penggunaan media pembelajaran videoscribe.

\section{Terdapat peningkatan motivasi belajar} setelah menggunakan media pembelajaran

\section{Videoscribe}

Pengujian hipotesis pertama digunakan untuk mengetahui perbedaan motivasi belajar peserta didik dari kelas kontrol serta kelas eksperimen. Peningkatan hasil motivasi belajar pada peserta didik dilihat dari hasil kuisioner yang telah dijawab sesudah dilakukannya perlakuan pada peserta didik. Hasil kecenderungan motivasi setelah dilakukannya perlakuan pada kelas kontrol yang memiliki kategori motivasi rendah sebesar 9,1\%, kategori sedang $72,7 \%$, kategori tinggi $18,2 \%$. Sedangkan untuk kelas eksperimen yang memiliki kategori motivasi rendah sebesar 0\%, kategori sedang 30,3\%, kategori tinggi $69,7 \%$.

Peningkatan motivasi belajar dari hasil pengujian hipotesis pertama didapatkan dari uji standard gain yang menunjukkan bahwa terdapat peningkatan yang signifikan dengan menggunakan media pembelajaran videoscribe. Dari hasil uji standard gain menunjukkan bahwa nilai standard gain kelas kontrol sebesar 0,28 yang tergolong rendah dan sebesar 0,46 pada kelas eksperimen yang tergolong sedang. Berdasarkan uji standard gain tersebut maka dapat dikatakan terdapat peningkatan motivasi belajar setelah menggunakan media belajar videoscribe.

Berdasarkan pada jawaban responden dihitung dengan skala likert didapatkan nilai rata-rata aspek yang paling tinggi terdapat pada aspek reaksi yang ditunjukkan siswa terhadap stimulus yang diberikan guru. Menurut peneliti aspek ini bernilai tinggi dilihat dari pengamatan dalam proses pembelajaran dimana peserta didik lebih memusatkan perhatian, mendengarkan serta aktif setelah diberikannya stimulus yang diberikan oleh guru. Hal ini sesuai dengan penelitian yang dilakukan oleh Taufiq Rahmat (2016) bahwa videoscribe dapat meningkatkan aktivitas belajar pada peserta didik. Sedangkan nilai terendah terdapat pada aspek rasa senang dalam mengerjakan tugas dari guru. Hal ini dipengaruhi oleh terbatasnya perangkat yang dimiliki siswa untuk mengerjakan tugas secara individu selain itu juga banyaknya tugas dari 
mata pelajaran lain. Pernyataan ini sesuai dengan Widyajayanti \& Istiqomah (2018) bahwa susah untuk memberikan tugas secara individu sesuai minat peserta didik sehingga mengakibatkan peserta didik kurang senang bila diberikan tugas. Maka dapat disimpulakn peningkatan motivasi ditunjukkan dari ratarata masing-masing indikator motivasi yang berbeda namun secara keseluruhan videoscribe dapat meningkatkan motivasi belajar siswa.

\section{Terdapat peningkatan hasil belajar setelah} menggunakan media pembelajaran

\section{Videoscribe}

Penggunaan media pembelajaran videoscribe mempengaruhi perbedaan peningkatan hasil belajar secara signifkan pada materi vektor. Hal ini dapat dilihat dari hasil uji independent sample t-test nilai Sig-2 tailed sebesar $0,001<0,05$ sehingga $\mathrm{H}_{\mathrm{a}}$ diterima dan $\mathrm{H}_{0}$ ditolak. Selain itu rata-rata posttest menjadi 76,6 dari nilai rata-rata sebelum adalah 65,1. dengan demikian dapat disimpulkan bahwa penggunaan videoscribe baik digunakan dalam peningkatan hasil belajar pada mata pelajaran dasar desain grafis materi vektor. Sebagaimana hasil penelitian dari Dellyardianzah (2017) menunjukkan penggunaan media videoscribe pada mata pelajaran ekonomi memperlihatkan hasil belajar siswa mengalami perbedaan peningkatan yang signifikan dilihat dari hasil post-test yang telah dilakukan

Peningkatan hasil belajar kognitif dalam pembelajaran didukung dengan media videoscribe sebagai penunjang penyedia visual materi yang dipelajari dalam dasar desain grafis. Hal ini didukung dengan teori Edgar Dale bahwa pembelajaran audiovisual dapat membantu peserta didik memahami pembelajaran dengan tingkat ingatan 50\% (Audie, 2019). Hal ini sejalan dengan pendapat Menurut Khoirudin (2017) menjelaskan bahwa videoscribe dapat memperjelas sesuatu hal yang bersifat abstrak, sehingga dapat membantu dalam pembelajaran Dasar Desain Grafis (Setiawan et al., 2019).

\section{Efektivitas penggunaan media pembelajaran Videoscribe untuk meningkatkan hasil belajar dan motivasi belajar peserta didik.}

Media videoscribe dapat dikatakan efektif dikarenakan penggunaan visual dalam belajar mata pelajaran dasar desain grafis dapat sangat membantu membangkitkan motivasi peserta didik sesuai dengan 5 indikator aspek motivasi. Aspek motivasi yang dimaksud yaitu perhatian, ketertarikan, tanggung jawab, rasa senang dan keterlibatan. Hal ini selaras dengan pendapat Ismail (2016), bahwa videoscribe membuat peserta didik lebih antusias, fokus perhatian serta daya tarik dalam mengikuti pembelajaran. Pada kelas eskperimen terlihat lebih banyak peserta didik memperhatikan pembelajaran. Hal ini selaras dengan hasil kuisioner dengan nilai tertinggi pada pernyataan "Saya lebih tertarik saat guru 
menjelaskan pembelajaran dengan media video".

Videoscribe dikatakan efektif dan dapat untuk meningkatkan motivasi serta hasil belajar secara signifikan. Hal ini sejalan dengan kajian teori menurut Suryani, Setiawan, \& Putria (2018: 84) bahwa videoscibe dapat memusatkan pehatian siswa sehingga pembelajaran lebih efektif dan dapat mendorong kemampuan berfikit imajinatif pada peserta didik. Hal ini juga sesuai dengan pendapat Ismail, E. Enawaty (2016) bahwa videoscribe memperlancar interaksi antara guru dengan peserta didik sehingga pembelajaran akan lebih efektif dan efisien sehingga pembelajaran yang guru berikan lebih mudah untuk tersampaikan dan tercapainya tujuan pembelajaran.

\section{SIMPULAN DAN SARAN}

\section{Simpulan}

Menurut rumusan masalah serta tujuan penelitian yang telah dipaparkan, maka dari penelitian ini dapat disimpulkan sebagai berikut :

1. Videoscribe terbukti dapat meningkatkan motivasi belajar pada mata pelajaran dasar desain grafis. Videoscribe mendorong siswa yang sebelumnya bermotivasi sedang menjadi bermotivasi tinggi, dan siswa bermotivasi rendah meningkat menjadi sedang.

2. Videoscribe terbukti meningkatkan hasil belajar siswa pada mata pelajaran dasar desain grafis. Hal tersebut berdasarkan analisa perhitungan uji t serta uji gain score, videoscribe diketahui meningkatkan hasil belajar siswa secara signifikan.

3. Penggunaan media pembelajaran videoscribe bisa dikatakan meningkatkan hasil belajar serta motivasi belajar dibandingkan tanpa menggunakan videoscribe.

4. Secara keseluruhan videsocribe bisa dikatakan meningkatkan hasil belajar dan motivasi belajar dikarenakan memiliki kemampuan untuk memberikan tampilan visual pada materi ajar yang dipelajari sehingga memudahkan siswa untuk memusatkan perhatian, memberikan rangsangan antusias yang mendorong interaksi guru serta memudahkan guru menyampaikan materi pembelajaran.

\section{Saran}

Dengan adanya pemaparan di atas, maka saran dalam penelitian ini sebagai berikut:

1. Peningkatan pada motivasi serta hasil belajar dalam menggunakan media pembelajaran videoscribe pendidik memiliki kendala susah dalam pengaturan audio dalam materi sehingga penjelasan masih secara langsung sehingga mengakibatkan ada peningkatan hasil belajar serta motivasi belajar namun tidak terlalu jauh antara kelas kontrol dengan kelas eksperimen.

2. Perlu diadakannya penelitian sejenis dengan materi yang sama namun mempertimbangkan kompetensi dasar 
keterampilan sehingga dapat dilihat hasil belajar dari segala aspek yaitu kognitif, afektif serta psikomotorik jadi tidak terbatas hanya pada aspek kognitif saja.

3. Media pembelajaran videoscribe pada penelitian ini dapat dijadikan referensi untuk meningkatkan motivasi dan hasil belajar namun pada penelitian selanjutnya terbuka luas untuk memilih media lain dalam pembelajaran.

\section{DAFTAR PUSTAKA}

Audie, N. (2019). Peran Media Pembelajaran Meningkatkan Hasil Belajar Peserta Didik. Prosiding Seminar Nasional Pendidikan FKIP, 2(1), 586-595.

Azis, R., Taiyeb, A. M., \& Muis, A. (2010). Pengaruh Penggunaan Video Pembelajaran Terhadap Motivasi dan Hasil Belajar Siswa Pada Materi Sistem Peredaran Darah The Effects of Learning Video on The Learning Motivation and Achievement Students in Material Circulation System. 461-466.

Dellyardianzah. (2017). Penggunaan Media

Pembelajaran Berbasis Video Scribe Untuk Meningkatkan Hasil Belajar Siswa Pada Mata Pelajaran Ekonomi. Pendidikan Dan Pembelajaran, 6(10), 17.

Giana, G. J., \& Lutfi, S. (2019). Pengembangan Media Pembelajaran Berbasis Video Tutorial Mata Pelajaran Dasar Desain Grafis Pada Kelas X Multimedia di SMK Negeri 1 Sakra. JIPTEK, Vol. 14 No. 2, 2021 $\begin{array}{lrr}\text { EDUMATIC: } & \text { Jurnal } & \text { Pendidikan } \\ \text { Informatika }, & 3(1), & 20 .\end{array}$ https://doi.org/10.29408/edumatic.v3i1.1 390

Hamalik, O. (2001). Proses Belajar Mengajar. PT. Bumi Aksara.

Hanafi, I. (2014). Pendidikan Teknik dan Vokasional. PT. Rafika Aditama.

Ismail, E. Enawaty, I. L. (2016). Pengaruh penggunaan media pembelajaran videoscribe terhadap hasil belajar siswa materi ikatan kimia. Portal Jurnal Ilmiah Universitas Tanjungpura (PJI-UNTAN), November, 1-10.

Munadi, Y. (2010). Media Pembelajaran (Sebuah Pendekatan Baru) (H. Syaf (ed.); Pertama). Gaun Persada (GP) Press.

Pranomo, W. W. (2014). Hubungan Motivasi Belajar Dengan Prestasi Belajar Siswa Kelas X Teknik Pemesinan Di Smk Antartika 1 Sidoarjo Wisnu Wibowo Pranomo Abstrak. 3, 114-120.

Rahman, M., \& Amri, S. (2014). Model Pembelajaran Aries Terintegratif (A. Kurniati (ed.); Pertama). PT. Prestasi Pustakarya.

Sadiman, A. S., Rahardjo, R., \& Haryono, A. (2018). Media Pendidikan. Raja Grafindo. Saputra, W. M. (2017). Pengaruh Penggunaan Media Audio Visual Dan Motivasi Terhadap Hasil Belajar Seni Budaya Sub Bidang Studi Seni Rupa Siswa Kelas Vii Smpn 6 Sungai Penuh. 102(4), 24-25. https://doi.org/10.1002/ejsp.2570

Setiawan, R. R., Awrus, S., \& Hakim, R. DOI: https://dx.doi.org/10.20961/jiptek.v14i2.46406 
(2019). Penggunaan Media

Pembelajaran Videoscribe Untuk

Meningkatkan Minat Dan Hasil Belajar

Seni Rupa Siswa di Kelas VIII2 SMP

NEGERI 3 PADANG.

Smaldino, S. E., Lowther, D. ., \& Russell, J.

D. (2011). Instructional Technology and

Media For Learning : Teknologi

Pembelajaran dan Media Untuk Belajar

(Sembilan). Kencana.

Sudjana, N. (2014). Penilaian Hasil Proses

Belajar Mengajar. Remaja Rosdakarya.

Suryani, N., Setiawan, A., \& Putria, A.

(2018). Media Pembelajaran Inovatif

dan Pengembangannya (jP. Latifah

(ed.); Pertama). PT Remaja Rosdakarya.

Taufiq Rahmat, F. (2016). Pengembangan

Media Materi Keadaan Alam Di

Indonesia Menggunakan Perangkat

Lunak Videoscribe Pada Mata Pelajaran

Ips Kelas VII. August.

Widyajayanti, \& Istiqomah. (2018). Analisis

Intensitas Pemberian Pekerjaan Rumah

(Pr) Dalam Meningkatkan Hasil Belajar

Matematika. Journal of Chemical

Information and Modeling, 53(9), 769-

774.https://doi.org/10.1017/CBO978110

7415324.004

Zulmiyetri, Z., Kasiyati, K., \& Kusumastuti,

G. (2019). Improving Reading Fluency

Through Videoscribe For Student with

Learning Disability. International

Journal of Research in Counseling and

Education, $2(2), \quad 9$.

https://doi.org/10.24036/0056za0002

JIPTEK, Vol. 14 No. 2, 2021 